\title{
Article
}

\section{The Dynamics of Selenium Uptake by Maize (Zea mays L.)}

\author{
Aldona Płaczek ${ }^{1, *}$ and Barbara Patorczyk-Pytlik ${ }^{2}$ \\ 1 Department of Plant Nutrition, Institute of Soil Science and Environmental Protection, \\ Wrocław University of Environmental and Life Sciences, Grunwaldzka St. 53, 50-357 Wrocław, Poland \\ 2 Department of Plant Nutrition, Wrocław University of Environmental and Life Sciences, Grunwaldzka St. 53, \\ 50-357 Wrocław, Poland; barbara.patorczyk-pytlik@gmail.com \\ * Correspondence: aldona.placzek@upwr.edu.pl
}

check for

updates

Citation: Płaczek, A.; Patorczyk-

Pytlik, B. The Dynamics of Selenium Uptake by Maize (Zea mays L.).

Agronomy 2021, 11, 1305. https:// doi.org/10.3390/agronomy11071305

Academic Editors: Raul Antonio Sperotto and Felipe Klein Ricachenevsky

Received: 16 May 2021

Accepted: 22 June 2021

Published: 27 June 2021

Publisher's Note: MDPI stays neutral with regard to jurisdictional claims in published maps and institutional affiliations.

Copyright: (c) 2021 by the authors. Licensee MDPI, Basel, Switzerland. This article is an open access article distributed under the terms and conditions of the Creative Commons Attribution (CC BY) license (https:/ / creativecommons.org/licenses/by/ $4.0 /)$.

\begin{abstract}
The dynamics of selenium (Se) uptake by two maize varieties (Zea mays L.) were assessed under two selenium doses ( 0.1 and $0.2 \mathrm{mg} \mathrm{kg}^{-1}$ of soil) applied to the soil. The addition of Se increased the biomass yield of the Se-susceptible variety (Bielik), while significantly decreasing the yield of the Se-resistant variety (Lober), and this suppression was stronger at the higher Se dose. The content and uptake of selenium by maize also increased with the Se dose, and the Bielik variety proved to be more effective. In terms of crop quality for animal nutrition, the optimal Se content (330-365 $\mu \mathrm{g} \mathrm{kg}^{-1}$ ) was reached after 81 days of vegetation under the lower Se dose only, while the higher treatment led to excessive Se accumulation in maize biomass.
\end{abstract}

Keywords: selenium; maize (Zea mays L.); uptake dynamic; biofortification; Se volatilization

\section{Introduction}

Selenium (Se) is an essential component of glutathione peroxidase, which can eliminate free radicals and peroxides in cells. This discovery gave rise to many studies on Se's role in the proper functioning of living organisms [1,2]. This micronutrient is found in a variety of organoselenium compounds (selenoamino acids, selenocysteine, selenomethionine and selenoproteins), which are significant for the resistance to permanent oxidation [3].

Selenium deficiency is thought to affect 800 million people worldwide. The World Health Organization (WHO) recommends a Se dietary intake of 55-200 $\mu \mathrm{g} \mathrm{day}^{-1}$ for adults. The minimal Se concentration in livestock feed is recommended at $50-100 \mu \mathrm{g} \mathrm{kg}^{-1}$ of dry forage mass [4]. Se deficiency may lead to dangerous diseases, such as muscular dystrophy and white muscle diseases, in calves and lambs [5,6]. Se deficiency in the daily diet may also inhibit growth, stimulate appetite, cause perinatal complications and decreased immunity in calves, as well as disturb iodine metabolism in cattle [7]. The bioavailability of selenium varies among animal species. Pigs are known to absorb Se in both its mineral and organic forms, while ruminants suffer more often from Se deficiency because rumen bacteria may reduce Se to inassimilable forms at low $\mathrm{pH}$ levels $[5,7]$.

During the last 20 years, many studies have been conducted on the possibility of increasing this nutrient in the daily diet of humans and animals. Biofortification through fodder crops may offer a natural and relatively safe method of supplying Se to animals. Plants accumulate selenium mainly in an inorganic form and then use it to synthesize the seleno-amino acids in selenomethionine, which thus becomes a source of Se's organic form for animals [8]. Compared to its inorganic compounds, organic Se compounds are characterized by much higher bioavailability for human and animal organisms $[9,10]$. The consumption of Se-enriched foods and fodder crops is considered an effective method of Se incorporation into the food chain, thus reducing the Se deficit in humans and animals [5].

Maize (Zea mays L.) is the most widely cultivated cereal crop in the world, used both for feed production for animals and grain-derived products for human consumption [11]. Attempts at maize biofortification with selenium have been undertaken in many countries 
using various application methods (soil or foliar fertilizers) and various Se forms (selenite, selenate, organic compounds and nano-selenium). However, maize's Se uptake ability may depend on many factors, such as the Se availability in the soil, the soil's properties ( $\mathrm{pH}$, redox potential, organic matter and clay mineral content, etc.), the climatic conditions and the maize variety [2,11-16]. Selenates tend to be more available to plants, but their use as fertilizers is associated with the risk of exceeding the optimal Se content in plant tissues. For maize, biofortification with Se may have a positive effect under field conditions at a rate of 100-200 $\mathrm{g} \mathrm{ha}^{-1}$ (as sodium selenite) [14].

Selenium in high concentrations can be toxic to humans and animals, and the boundary between its acceptable and excessive content is extremely narrow. On the other hand, the content of selenium in plants may depend on the length of the growing season. During vegetation, the selenium content may decrease due to the plant dilution effect. This effect occurs when the dry-weight accumulation increases at a faster rate than mineral-nutrient accumulation. Conversely, an increased mineral-nutrient concentration will result when the mineral-nutrient accumulation increases at a faster rate than dry-weight accumulation [17].

The period between the Se application and the time the plants become suitable for animal feeding may be lengthy [18]. Hence, determining a safe Se dose in plant biofortification, defining the dynamics of selenium uptake by plants and identifying the appropriate vegetation phase in which plants intended for fodder production will contain the optimal selenium content are key tasks for researchers. The aim of this study was to assess the effect of selenium applied to the soil on the dynamics of Se uptake by maize plants.

\section{Materials and Methods}

\subsection{Soil}

Soil from the plough layer $(0-20 \mathrm{~cm})$ collected in Przeworno, SW Poland $\left(50^{\circ} 41^{\prime} 54^{\prime \prime} \mathrm{N}\right.$ $17^{\circ} 09^{\prime} 46^{\prime \prime} \mathrm{E}$ ), was used in this experiment. The soil had the texture of loamy sand and a slightly acidic reaction $\left(\mathrm{pH}_{\mathrm{KCl}}\right.$ 6.1). The content of total Se and soluble Se in diethylenetriaminepentaacetic acid (DTPA) was 143 and $13.8 \mu \mathrm{g} \mathrm{kg}^{-1}$, respectively, which falls below the mean Se concentration of soils throughout the world $\left(0.4 \mathrm{mg} \mathrm{kg}^{-1}\right.$, ranging from 0.01 to $2 \mathrm{mg} \mathrm{kg}^{-1}$ ) [19]. The soil was dried, sieved through a $2 \mathrm{~mm}$ mesh and evenly mixed with macro- and micronutrients (N, P, K, Mg, Na, Cu, Fe, B, Mn, Mo and Zn) applied in a doses of $0.5,0.4,0.5$ and $0.3 \mathrm{~g} \mathrm{pot}^{-1}$ and 75, 3, 30, 3, 20, 1 and $5 \mathrm{mg} \mathrm{pot}^{-1}$, respectively. The experiment was conducted in pots containing $5 \mathrm{~kg}$ of soil.

\subsection{Plant Material and Experimental Design}

The experiment was conducted in a greenhouse (Department of Plant Nutrition, Wrocław University of Environmental and Life Sciences, Poland, 51 ${ }^{\circ} 10^{\prime} 25^{\prime \prime} \mathrm{N} 17^{\circ} 06^{\prime} 52^{\prime \prime} \mathrm{E}$ ) and arranged in a completely randomised design with three replicates and three factors. The two maize varieties (Lober: FAO 240 and Bielik: FAO 230-240, both of which are a mid-early trilinear hybrid) used as test plants differ in their ability to accumulate Se at its natural (low) content in soil [16]. Three Se treatments, applied before maize sowing, included 0 Se (no Se addition; a control), $0.1 \mathrm{mg} \mathrm{Se} \mathrm{kg}^{-1}$ of soil and $0.2 \mathrm{mg} \mathrm{Se} \mathrm{kg}^{-1}$ of soil. Selenium was applied as an aqueous $\mathrm{Na}_{2} \mathrm{SeO}_{4}$ solution, which was uniformly mixed with the soil. Twelve seeds of maize per pot were sown, and the plant number was reduced to six per pot ten days after emergence. The soil in a pot was maintained at $60 \%$ of the maximum water capacity. Maize was harvested at four terms: after 23 days of vegetation (BBCH 16, six leaves unfolded), after 38 days (BBCH 19, nine or more leaves unfolded), after 64 days (BBCH 51, beginning of tassel emergence) and after 85 days (BBCH 70, beginning of grain development) [20]. The six plants per pot were harvested just above the soil surface, cut into small pieces and dried at room temperature, i.e., 20-30 ${ }^{\circ} \mathrm{C}$, to avoid Se losses by methylation, until a constant weight was achieved. Then the biomass yield (dry matter) was weighed, and the plant material was ground for further chemical analysis. 


\subsection{Estimation of Se Content in Plants}

The amount of selenium in the plants was determined after sample digestion with a heated mixture of methanol, Triton X-100 (1:10 solution), $40 \%$ magnesium nitrate $\left(\mathrm{MgNO}_{3}\right.$ $6 \mathrm{H}_{2} \mathrm{O}$ ) and concentrated nitric acid [21]. The samples were placed on a heating plate where the temperature gradually increased from $75^{\circ} \mathrm{C}$ to $200{ }^{\circ} \mathrm{C}$ within $20 \mathrm{~h}$. Then the samples were transferred to a muffle furnace for further digestion at $500^{\circ} \mathrm{C}$ for $4 \mathrm{~h}$. The residues were dissolved with diluted $\mathrm{HCl}(1: 1)$ and heated for $1 \mathrm{~h}$ at $95^{\circ} \mathrm{C}$. The solution was then quantitatively transferred to a $50 \mathrm{~cm}^{3}$ volumetric flask. The Se content in the extracts was determined by atomic absorption spectrophotometry (AAS) in combination with hydride generation (Spectra 220 FS + VGA-76 adapter, Varian Australia Pty Ltd., Sydney, Australia). All measurements were performed twice for each sample, and the results shown in this study are their mean values. The measurements were optimised by determining the repeatability and recovery from the reference plant material (INCTTL-1) with the certified Se content of $0.076 \mathrm{mg} \mathrm{kg}^{-1}$, obtaining an average recovery of $97 \%$ and a relative error of $4 \%$.

\subsection{Relative Rate of Dry Mass Accumulation and Relative Rate of Selenium Uptake by Maize}

Due to the different harvest dates and different lengths of vegetation $(19,34,60$ and 81 days from emergence), the relative rate of dry mass accumulation and relative rate of selenium uptake by plants were selected as indicators of plant growth. These values were calculated by dividing the yield by the number of vegetation days since emergence $(\mathrm{BBCH} 09)$ or, for the remaining harvest dates, by the number of days that had elapsed since the previous phase. That value was then divided by 6 , the number of plants in the pot.

Relative Rate of Dry Mass Accumulation $(\mathbf{R M G})=\frac{\text { Yield }_{\mathrm{Tn}}}{\left(\Delta \mathbf{d}_{\mathrm{Tn}-1}\right)} / 6\left(\mathrm{~g} \mathrm{plant}^{-1} \mathrm{day}^{-1}\right)$

Yield $_{\mathrm{Tn}}$ - plant dry mass [g pot ${ }^{-1}$ ] harvested at Tn;

Tn-phase of plant growth/harvest;

$\Delta \mathbf{d}_{\mathrm{Tn}-1}$-number of days since previous harvest phase.

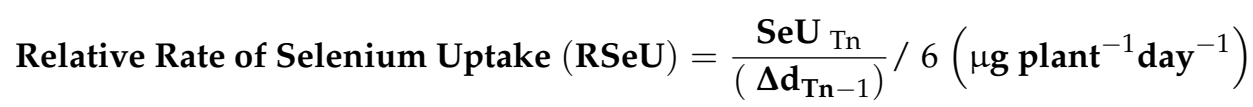

$\mathrm{SeU}_{\mathrm{Tn}}$-Se uptake $\left[\mu \mathrm{g} \mathrm{pot}^{-1}\right]$ by plants harvested at Tn;

Tn-phase of plant growth/harvest;

$\Delta \mathbf{d}_{\mathrm{Tn}-1}$-number of days since previous plant harvest phase.

$$
\text { Selenium Uptake }(\mathrm{SeU})=\frac{\text { Yield }_{\mathrm{Tn}} \times \mathrm{SeC}}{1000 \mathrm{gn}}\left(\mu \operatorname{g~pot}^{-1}\right)
$$

Yield ${ }_{\mathrm{Tn}}$ - plant dry mass [g pot $\left.{ }^{-1}\right]$ harvested at Tn;

Tn-phase of plant growth/harvest;

$\mathrm{SeC}_{\mathrm{Tn}}$-Se content $\left[\mu \mathrm{g} \mathrm{kg}^{-1}\right]$ in plants harvested at $\mathrm{Tn}$.

\subsection{Statistical Analysis}

Statistica 8.0 software was used for the statistical analysis. Analysis of variance (ANOVA) was employed to detect the significance of the treatment effects while least significant difference (LSD) tests at $p<0.05$ were utilised to compare the differences between means. 


\section{Results and Discussion}

\subsection{Plant Yield}

The yield of the above-ground maize biomass varied depending on the vegetation stage, selenium dose and varietal properties (Table 1, Figure 1). In general, the Lober variety provided a higher average biomass yield than did the Bielik variety, although the varietal differences in yield appeared mainly in the latter vegetation stages $(\mathrm{BBCH} 51$ and $\mathrm{BBCH} 70)$.

Table 1. Plant yield, selenium content and uptake by maize (Zea mays L.).

\begin{tabular}{|c|c|c|c|c|c|}
\hline & $\begin{array}{c}\text { Yield } \\
\left(\mathrm{g} \mathrm{pot}^{-1}\right)\end{array}$ & $\begin{array}{c}\text { RMG } \\
\left(\text { g plant }^{-1} \text { day }^{-1}\right)\end{array}$ & $\begin{array}{l}\text { Se Content } \\
\left(\mu \mathrm{g} \mathrm{kg}^{-1}\right)\end{array}$ & $\begin{array}{l}\text { Se uptake } \\
\left(\mu g \operatorname{pot}^{-1}\right)\end{array}$ & $\begin{array}{c}\text { RSeU } \\
\left(\mu \text { plant }^{-1} \text { day }^{-1}\right)\end{array}$ \\
\hline \multicolumn{6}{|l|}{ Variety $(\mathrm{A})$} \\
\hline LOBER & $\begin{array}{c}77.9 \\
(7.45-156)\end{array}$ & $\begin{array}{c}0.24 \\
(0.00-0.52)\end{array}$ & $\begin{array}{c}835 \\
(10.0-2670)\end{array}$ & $\begin{array}{c}45.3 \\
(0.45-179)\end{array}$ & $\begin{array}{c}0.09 \\
(-0.61-0.72)\end{array}$ \\
\hline BIELIK & $\begin{array}{c}71.0 \\
(8.97-140)\end{array}$ & $\begin{array}{c}0.22 \\
(0.00-0.43)\end{array}$ & $\begin{array}{c}992 \\
(28.0-2774)\end{array}$ & $\begin{array}{c}50.2 \\
(0.68-186)\end{array}$ & $\begin{array}{c}0.10 \\
(-0.52-0.72)\end{array}$ \\
\hline \multicolumn{6}{|c|}{ Se dose $\left(\mathrm{mg} \mathrm{kg}^{-1}\right)(\mathrm{B})$} \\
\hline 0 & $\begin{array}{c}73.3 \\
(7.45-152)\end{array}$ & $\begin{array}{c}0.28 \\
(0.06-0.46)\end{array}$ & $\begin{array}{c}41.5 \\
(10.0-82.0)\end{array}$ & $\begin{array}{c}2.17 \\
(0.45-5.40)\end{array}$ & $\begin{array}{c}0.01 \\
(-0.01-0.02)\end{array}$ \\
\hline 0.1 & $\begin{array}{c}74.7 \\
(9.07-156)\end{array}$ & $\begin{array}{c}0.29 \\
(0.08-0.51)\end{array}$ & $\begin{array}{c}862 \\
(324-1696)\end{array}$ & $\begin{array}{c}41.5 \\
(10.9-67.3)\end{array}$ & $\begin{array}{c}0.12 \\
(-0.16-0.43)\end{array}$ \\
\hline 0.2 & $\begin{array}{c}75.4 \\
(9.62-154) \\
\end{array}$ & $\begin{array}{c}0.28 \\
(0.08-0.52) \\
\end{array}$ & $\begin{array}{c}1838 \\
(662-2774) \\
\end{array}$ & $\begin{array}{c}99.6 \\
(25.06-187)\end{array}$ & $\begin{array}{c}0.25 \\
(-0.61-0.72)\end{array}$ \\
\hline \multicolumn{6}{|l|}{$\mathrm{BBCH}(\mathrm{C})$} \\
\hline ВВСН09 & - & 0.00 & - & - & 0.00 \\
\hline BВCH16 & $\begin{array}{c}9.43 \\
(7.45-11.1)\end{array}$ & $\begin{array}{c}0.08 \\
(0.06-0.10)\end{array}$ & $\begin{array}{c}1382 \\
(55.0-2774)\end{array}$ & $\begin{array}{c}13.5 \\
(0.45-29.7)\end{array}$ & $\begin{array}{c}0.12 \\
(0.00-0.26)\end{array}$ \\
\hline BBCH19 & $\begin{array}{c}37.7 \\
(33.3-41.0)\end{array}$ & $\begin{array}{c}0.31 \\
(0.27-0.35)\end{array}$ & $\begin{array}{c}1166 \\
(30.0-2548)\end{array}$ & $\begin{array}{c}44.7 \\
(1.00-92.8)\end{array}$ & $\begin{array}{c}0.35 \\
(0.01-0.72)\end{array}$ \\
\hline ВBCH51 & $\begin{array}{c}106 \\
(97.9-120)\end{array}$ & $\begin{array}{c}0.44 \\
(0.38-0.52)\end{array}$ & $\begin{array}{c}722 \\
(20.0-1811)\end{array}$ & $\begin{array}{c}77.6 \\
(2.13-186)\end{array}$ & $\begin{array}{c}0.21 \\
(0.00-0.60)\end{array}$ \\
\hline ВВСH70 & $\begin{array}{c}144 \\
(131-156)\end{array}$ & $\begin{array}{c}0.30 \\
(0.23-0.37) \\
\end{array}$ & $\begin{array}{c}385 \\
(10.0-919)\end{array}$ & $\begin{array}{c}55.1 \\
(1.52-121)\end{array}$ & $\begin{array}{c}-0.18 \\
(-0.61-0.05)\end{array}$ \\
\hline A & ${ }^{*} \mathrm{LSD}_{0.05} 0.83$ & ${ }^{*} \mathrm{LSD}_{0.05} 0.01$ & ${ }^{*} \mathrm{LSD}_{0.05} 28.36$ & ${ }^{*} \mathrm{LSD}_{0.05} 2.25$ & ns \\
\hline B & ${ }^{*} \mathrm{LSD}_{0.05} 1.01$ & ns & ${ }^{*} \mathrm{LSD}_{0.05} 34.74$ & ${ }^{*} \mathrm{LSD}_{0.05} 2.75$ & ${ }^{*} \mathrm{LSD}_{0.05} 0.02$ \\
\hline $\mathrm{C}$ & ${ }^{*} \mathrm{LSD}_{0.05} 1.17$ & ${ }^{*} \mathrm{LSD}_{0.05} 0.01$ & ${ }^{*} \mathrm{LSD}_{0.05} 40.11$ & ${ }^{*} \mathrm{LSD}_{0.05} 3.18$ & ${ }^{*} \mathrm{LSD}_{0.05} 0.03$ \\
\hline $\mathrm{A} \times \mathrm{B} \times \mathrm{C}$ & ${ }^{*} \mathrm{LSD}_{0.05} 2.87$ & ${ }^{*} \mathrm{LSD}_{0.05} 0.02$ & ${ }^{*} \mathrm{LSD}_{0.05} 98.25$ & ${ }^{*} \mathrm{LSD}_{0.05} 7.78$ & ${ }^{*} \mathrm{LSD}_{0.05} 0.07$ \\
\hline
\end{tabular}

All of the data are expressed as mean (and minimum-maximum in brackets) value; ${ }^{*} \operatorname{LSD}_{0.05}$-significant differences at $p \leq 0.05$ according to Duncan's multiple-range test; ns-non-significant at $p \leq 0.05 ; \mathrm{BBCH}$ plant vegetation phases; RMG relative rate of dry mass accumulation; $\mathrm{RSeU}$ relative rate of selenium uptake by plants.

Selenium present in a low concentration in soil can act as an antioxidant and stimulate plant growth. At high and toxic concentrations, however, Se's impact on plant yield is negative, causing metabolic disturbances [22]. Such a reaction was observed in maize, which at low doses of soil selenate yielded at a higher level than did the control plants. Considerable reduction was observed in dry matter, root length, antioxidant enzymes and other physiological parameters at the selenium level of $20 \mathrm{mg} \mathrm{kg}^{-1}$ [23].

The beneficial effect of Se fertilization on plant biomass may be related to its influence on the rate of photosynthesis and the higher biosynthesis of chlorophyll [24]. Selenium may also increase maize yield under stress conditions, such as soil salinity or soil contamination with metals, such as cadmium or arsenium, by reducing these conditions' negative effects. Se can protect the plant against oxidative damage by increasing the activity of antioxidant enzymes and influencing the concentration of non-enzymatic antioxidants (phenolics and flavonoids) [25-27]. 


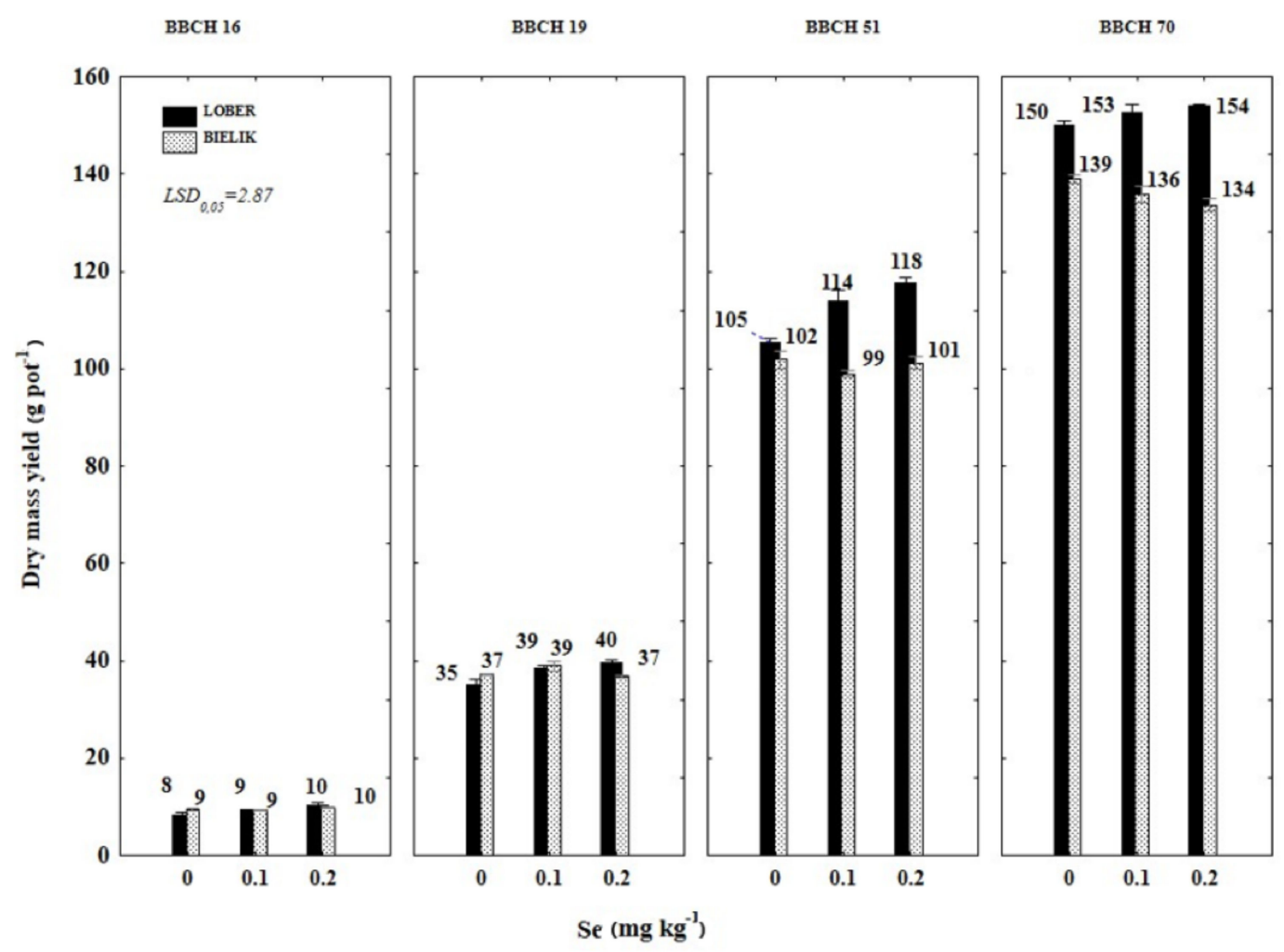

Figure 1. Effect of selenium dose on dry mass of two maize varieties $\left(\mathrm{g} \mathrm{pot}^{-1}\right)$ at subsequent growth stages.

Figure 1 presents the different yield responses of the maize varieties to selenium. Dry matter of the Lober variety was higher than that of the control in all vegetation stages. Moreover, Lober yields responded positively to the higher Se dose. At the dose of $0.1 \mathrm{mg} \mathrm{kg}^{-1}$, the maize dry mass in the BBCH16 phase was $11 \%$ higher than in the control, but in the $\mathrm{BBCH} 70$ phase, it was only $2 \%$ higher than in the control. At the higher Se dose $\left(0.2 \mathrm{mg} \mathrm{kg}^{-1}\right)$, the crop yield was also higher by $23 \%$ and $3 \%$ in the $\mathrm{BBCH} 16$ and $\mathrm{BBCH}$ 70 phases, respectively.

The influence of Se on maize yield may depend on the Se dose but also on the chemical form and the method of its application. In this study, sodium selenate was used due to its greater efficiency, compared to selenites or Se organic compounds, in increasing the selenium level in plants. Plants can easily absorb selenates and then effectively translocate them to shoots [28,29]. A positive response to sodium selenate on maize yield was found after Se was applied to soil at doses of $10-40 \mathrm{mg} \mathrm{ha}^{-1}$ [15]. A similar positive on plant yield was found at low selenium doses in ryegrass $\left(0.1-2.0 \mathrm{mg} \mathrm{kg}^{-1}\right.$ soil) [30], lentil (2.2 $\mu \mathrm{g} \mathrm{g}^{-1}$ soil) [31] and rice ( $0.75 \mathrm{mg} \mathrm{kg}^{-1}$ soil) [32].

This study confirmed no significant effect of Se on plant yield in the Bielik variety during the early vegetation stages. However, in the later growth phases, Se application resulted in a significant reduction in plant dry mass compared to the control, especially at the higher Se dose (Figure 1).

High concentrations of selenates in the soil may negatively affect plant growth. This phenomenon has been observed after selenium was applied to the soil at doses of $0.4-10 \mathrm{mg} \mathrm{kg}^{-1}$ in ryegrass [30], at a dose of $4 \mathrm{mg} \mathrm{kg}^{-1}$ in rapeseed [33] and at a dose of $2 \mathrm{mg} \mathrm{kg}^{-1}$ in wheat [28]. In our study, a negative effect on maize dry mass was found in the Bielik variety at a selenium dose of $0.2 \mathrm{mg} \mathrm{kg}^{-1}$.

Figure 2 reveals that the relative rate of dry mass accumulation of the maize plants increased with the selenium dose, reaching its maximum value at the beginning of the tassel emergence phase (BBCH 51). Over the 21 days that followed, the relative rate of dry matter accumulation was lower by $24 \%$ (in Lober) and $44 \%$ (in Bielik) than in the BBCH 51 phase. The control plants of the Bielik variety exhibited a higher average dry matter 
accumulation in the early stages of vegetation than did the Lober variety. However, the daily increase in dry matter accumulation in the Bielik variety was lower by $8 \%$ in the $\mathrm{BBCH} 51$ phase and by $17 \%$ in the $\mathrm{BBCH} 70$ phase than in the Lober variety.

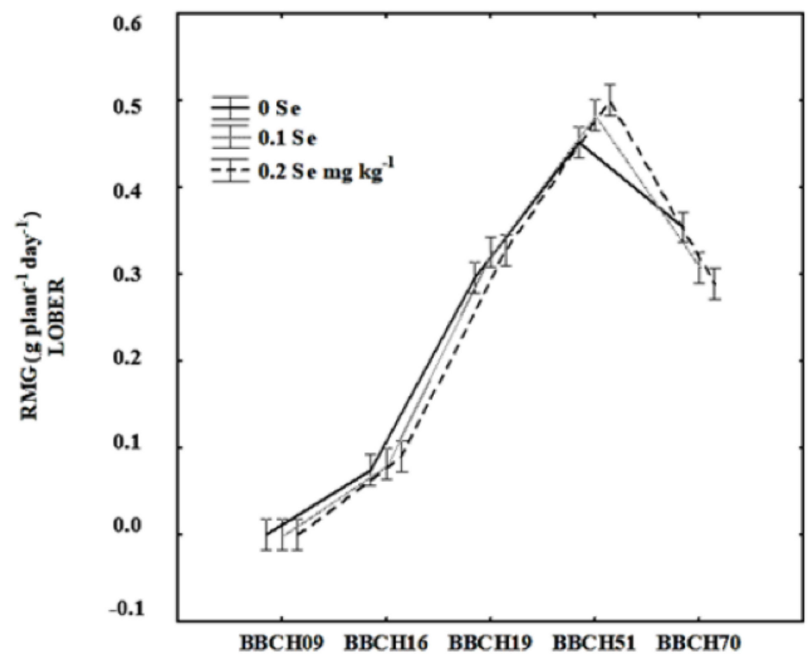

(a)

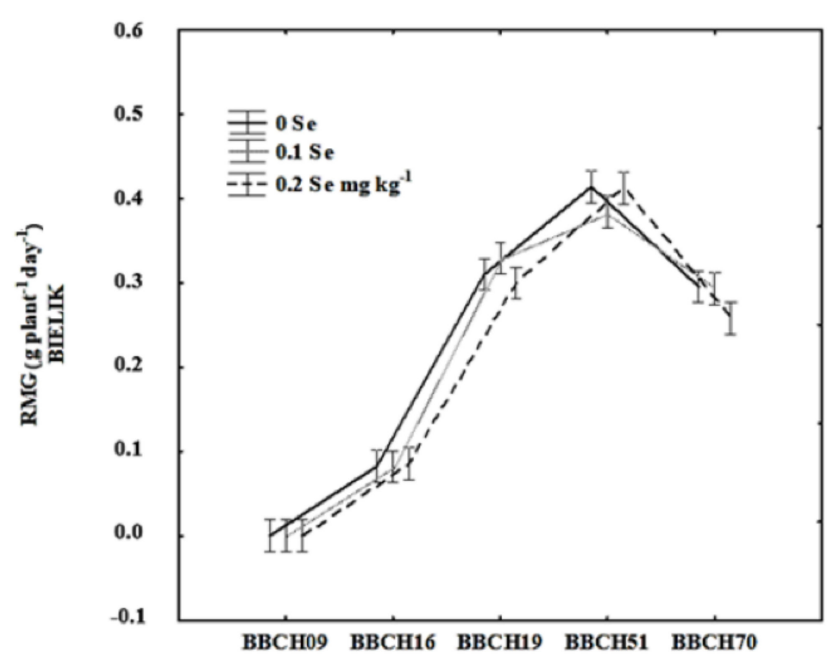

(b)

Figure 2. Effect of selenium dose on the relative rate of dry mass accumulation (RMG) (g plant ${ }^{-1}$ day $^{-1}$ ) of two maize varieties: (a) Lober and (b) Bielik, at subsequent growth stages.

The effect of selenium on the relative dry matter accumulation of maize depended on the vegetative phase and the varietal properties of the plants. Selenium had a positive effect on the dry mass accumulation of the Lober variety until the BBCH 51 phase, up to which the RMG value was by 11 to $7 \%$ (Se at $0.1 \mathrm{mg} \mathrm{kg}^{-1}$ ) and by 22 to $10 \%$ (Se at $0.2 \mathrm{mg} \mathrm{kg}^{-1}$ ) higher at subsequent growth stages than in the control plants. Over the 21 days of vegetation that followed, the effect of selenium on the relative rate of dry mass accumulation was negative.

A different dynamic was found in the Bielik variety. In the early vegetation stages, selenium exerted no effect on the daily increase in dry matter. Between the BBCH 51 and $\mathrm{BBCH} 70$ phases, however, the higher Se dose suppressed the RMG value.

\subsection{Selenium in Plants}

The Se content in cereal foods-the main selenium source in the human diet-can range from 0.1 to $0.3 \mathrm{mg} \mathrm{kg}^{-1}$. Meanwhile, Se-fortified foods account for only $6 \%$ of human's total Se intake [34]. This study demonstrated that maize belongs to the group of plants with a high ability to accumulate selenium in its above-ground parts. A similar positive effect in increasing the selenium content in various maize organs was found as a result of Se soil fertilization $[11,15,35]$. To analyse the uptake of nutrients, including selenium, by various plant organs, it is necessary to understand the factors influencing their bioavailability from the soil during the entire growing season [36].

Selenium content in the plants' dry matter depended significantly on the Se dose, the vegetation stage and the varietal properties (Table 1). Plants collected from soil with a natural Se content contained less than $100 \mu \mathrm{g} \mathrm{kg}^{-1}$ of selenium, which fails to meet the daily requirement of this microelement for animals [37].

The Bielik plants contained on average $18 \%$ more selenium in dry matter than did the Lober plants, and the varietal differences persisted after the application of the selenium to the soil. The lower Se dose of $0.1 \mathrm{mg} \mathrm{kg}^{-1}$ resulted in a 21-fold increase in the Se content of maize shoots of the Bielik variety in the BBCH 16 phase, while at the higher Se dose $\left(0.2 \mathrm{mg} \mathrm{kg}^{-1}\right)$, this value was 45 times higher in the Lober variety and 36 times higher in the Bielik variety than in the control plants. The higher Se content in Bielik plants may be 
associated with the occurrence of two phenomena. First, the higher Se concentration in plants may occur when this value increases at a faster rate than dry-weight accumulation. Second, the lower content of accumulated dry mass in Bielik plants might be as a result of excessive or even toxic amounts of selenium taken up by plants, which could interfere with photosynthesis processes, thus limiting the yield of plants.

As the plants' growth progressed, however, the selenium content in the maize shoots decreased, and this decrease may be related to the rapid increase in dry matter and the occurrence of the dilution effect [36]. The Se content in the $\mathrm{BBCH} 70$ phase was, on average, $23 \%$ (Lober) and $32 \%$ (Bielik) lower than in the BBCH 16 phase of the same plants. After 81 days of vegetation, the selenium content in Se-fortified maize remained excessiveexceeding the standards of animal nutrition, especially at the higher Se dose. In addition, in the last vegetation stage, the Bielik variety contained approximately $200 \mu \mathrm{g} \mathrm{kg}{ }^{-1}$ more selenium than did the Lober variety (Figure 3).

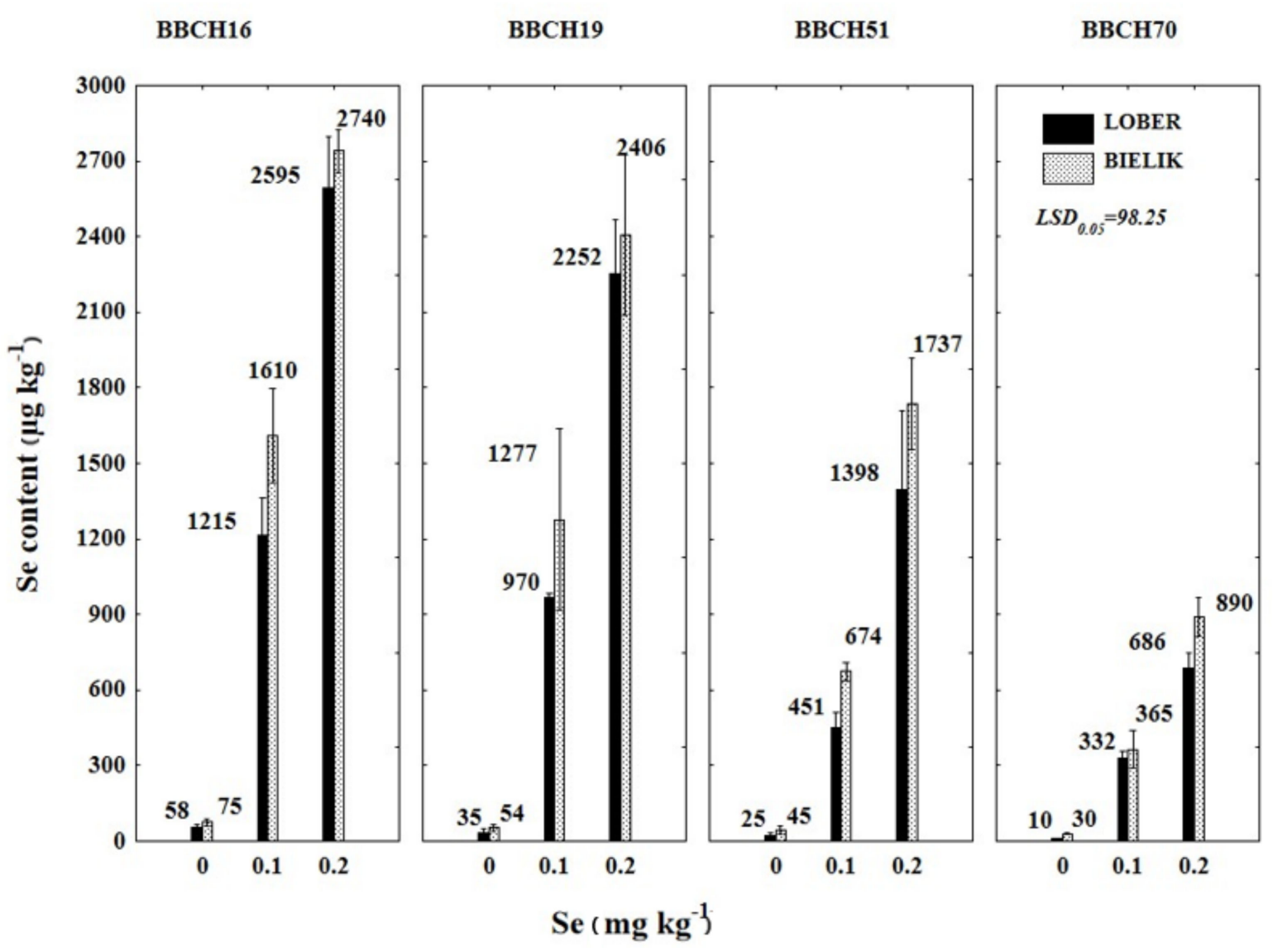

Figure 3. Effect of selenium dose on Se content $\left(\mu \mathrm{g} \mathrm{kg}^{-1}\right)$ in two maize varieties at subsequent growth stages.

According to Song et al. (2018), the changes in selenium content and translocation in various vegetation stages was found in maize under the field treatment, suggesting that the selenium content of maize may be plant organ dependent. From the tillering stage to the mature stage, a significant gradual decrease in the Se content of the leaves and a significant increase in the Se content of the stems occurred. These dynamics may indicate that the Se content of the grains is derived mainly from the leaves-perhaps because maize is a high-stalk plant, which, at the maturity stage, exhibits weak Se translocation from the stems to the leaves and grains. Furthermore, the changes in the Se content of maize grain shows a trend similar to that observed in rice and soybeans [36].

Selenium fertilization may affect Se concentrations of the shoots and roots of maize plants in a dose-dependent manner. Previous research has demonstrated that when the sodium selenate concentration in the soil was increased at $\mathrm{Na}_{2} \mathrm{SeO}_{4}$ doses of $0-20 \mathrm{mg} \mathrm{kg}^{-1}$, 
the Se content of maize plants also increased after 60 days of vegetation [23]. Significantly more selenium-corresponding to an increasing Se dose in the soil-was also found in various crop species, such as rice [38], soybeans [39], oilseed rape [1,40] and buckwheat [41].

A study investigating the effect of Se soil fertilization at doses of $0-100 \mathrm{~g} \mathrm{ha}^{-1}$ on the Se content of rice crops revealed that the selenium content in various parts of the plants significantly increased as the Se level in the soil increased. However, a significant decrease in the Se content of the shoots and roots also occurred from the tillering stage to the mature stage [38].

The intensity of selenium uptake by plants may depend on many factors, including the species and phase of vegetation, the Se content in the soil and its bioavailability for plants, the physiological conditions (salinity and soil $\mathrm{pH}$ ), the presence of other substances, the activity of membrane transporters and the plant translocation mechanism [42-44]. In general, the maize shoots of the Bielik variety exhibited a higher average Se uptake than did those of the Lober variety (Table 1). Meanwhile, the varietal properties appeared to have no effect on the Se uptake in the control, and these plants accumulated less than $10 \mu \mathrm{g} \mathrm{pot}^{-1}$ of selenium throughout the entire growth period (Figure 4). The Se soil application resulted in a significant increase in the maize plants' Se uptake until the BBCH 51 phase (most intensively between the sixth and ninth leaf phases). In the 21 days of vegetation that followed, the plants' selenium accumulation was limited and dependent on the Se dose as well as on the variety's properties. According to Young et al. (2003), a decrease in selenium content and Se uptake by plants in the late vegetation stage might be connected to a nutrient dilution caused by a biomass increase or decrease in the soil-available Se or the plants' transformation from vegetative to reproductive growth [38]. In this study, the dilution effect, which relates to the rapid increase in dry matter, might occur, causing a decrease in selenium concentration per $1 \mathrm{~kg}$ of dry matter in the latter vegetation stage. As further studies show, the decrease in selenium content in plants may also be associated with the volatilization of Se volatile forms from the leaf surface. In the BBCH 70 phase, selenium uptake decreased by $1 \%$ (at a dose of $0.1 \mathrm{mg} \mathrm{kg}^{-1}$ ) and $36 \%$ (at a dose of $0.2 \mathrm{mg} \mathrm{kg}^{-1}$ ) in the Lober variety and by $26 \%$ and $32 \%$, respectively, in the Bielik variety (Figure 4 ).

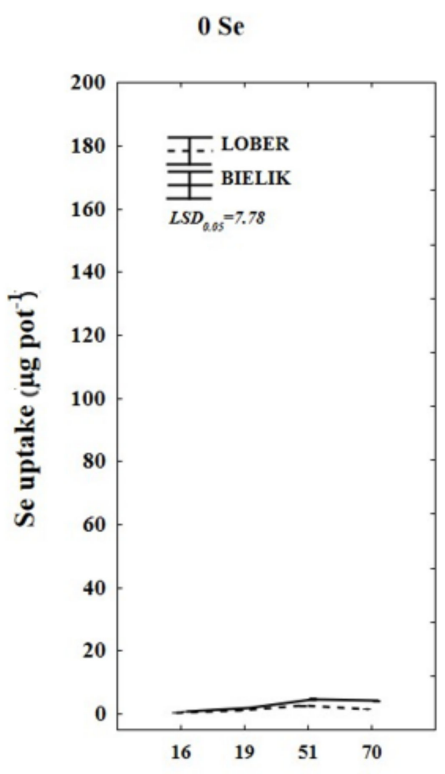

$0.1 \mathrm{Se}\left(\mathrm{mg} \mathrm{kg}^{-1}\right)$

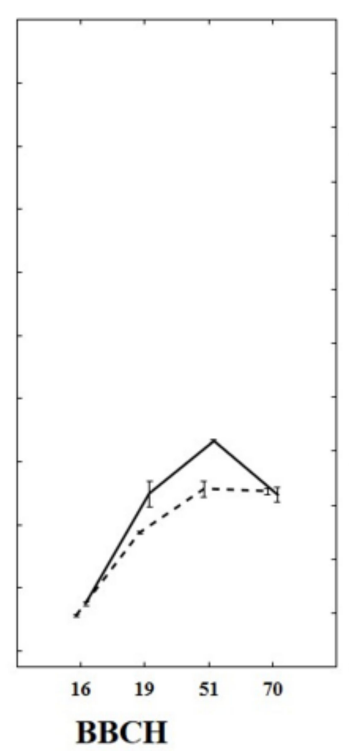

$0.2 \mathrm{Se}\left(\mathrm{mg} \mathrm{kg}^{-1}\right)$

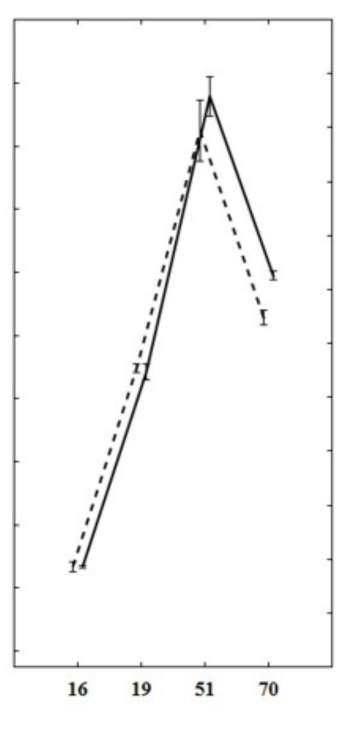

Figure 4. Effect of selenium dose on Se uptake $\left(\mu \mathrm{g} \mathrm{pot}^{-1}\right)$ by two maize varieties at subsequent growth stages.

\subsection{Rate of SE Uptake (RSeU)}

Figure 5 shows the effect of the selenium dose on the relative rate of Se uptake (RSeU) by maize at subsequent growth stages. No significant effect of the varietal properties was 
found. However, the selenium treatment affected the RSeU value. The relative rate of selenium accumulation increased with days for maize vegetation, reaching its maximum value in the BBCH 19 phase. Subsequently, Se fertilization resulted in a significant decrease in the daily selenium uptake of one plant from the $\mathrm{BBCH} 19$ phase to the $\mathrm{BBCH} 51$ phase. Compared to the previous phase, the RSeU value in the $\mathrm{BBCH} 51$ phase at the Se dose of $0.1 \mathrm{mg} \mathrm{kg}^{-1}$ was lower in the Lober and Bielik varieties by $23 \%$ and $9 \%$, respectively. At the higher selenium dose of $0.2 \mathrm{mg} \mathrm{kg}^{-1}$, the daily Se uptake by one maize plant decreased by $65 \%$.

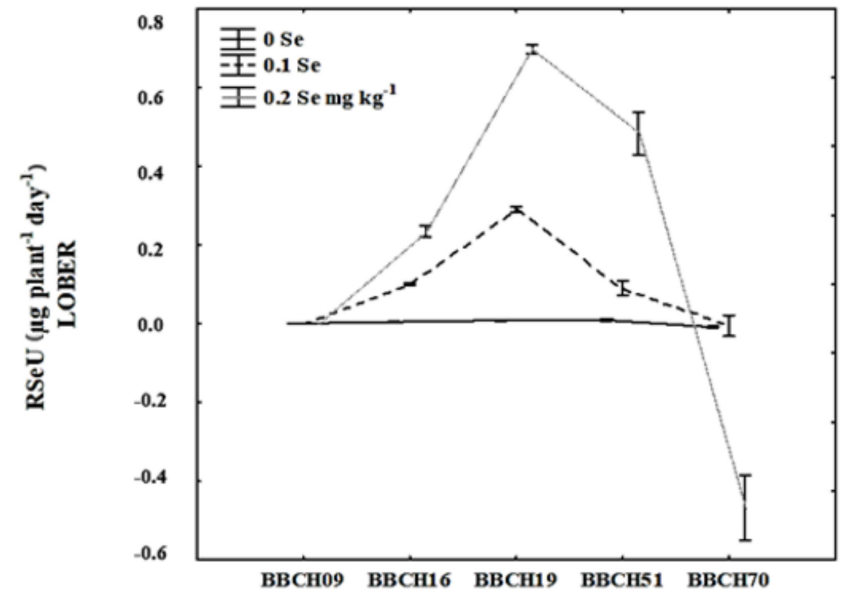

(a)

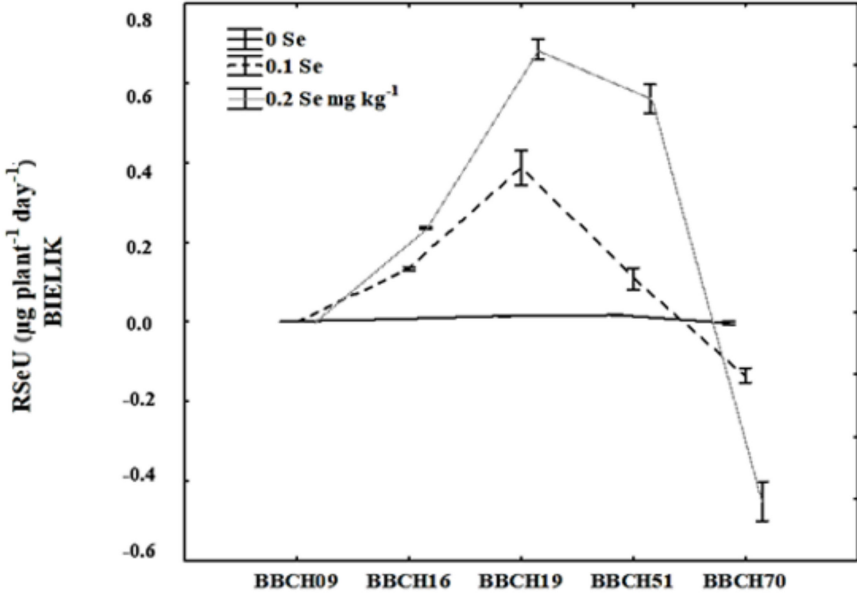

(b)

Figure 5. Effect of selenium dose on the relative rate of Se uptake (RSeU) $\left(\mu g\right.$ plant $^{-1}$ day $\left.^{-1}\right)$ by two maize varieties: (a) Lober and (b) Bielik, at subsequent growth stages.

The relative rate of Se uptake by maize was negative at the $\mathrm{BBCH} 71$ phase in both varieties, which may indicate the loss of selenium from plant tissue as a result of the methylation process. The methylation of the amino acids selenomethionine and selenocysteine can be activated in plants under high levels of selenium accumulation, resulting in the production of methyl-SeMet and methyl-SeCys [43]. Both of the resulting compounds are precursors to the volatile selenium species DMSe and DMDSe, respectively. The synthesis of dimethyl selenide is most common in non-Se hyperaccumulator plants. Biomethylation in plants is seen as a detoxification effect because methylated forms of Se are less toxic. In addition, high selenium concentrations may provoke a defence mechanism against excessive Se accumulation inside plant cells $[45,46]$. In this study, the highest daily Se loss from a single maize plant $\left(0.2 \mathrm{mg} \mathrm{kg}^{-1}\right)$ occurred in the $\mathrm{BBCH} 71$ phase, and the loss fluctuated on average at $0.46 \mu \mathrm{g} \mathrm{plant}^{-1}$ day $^{-1}$.

\section{Conclusions}

Maize biofortification with selenium may facilitate incorporating this element into the daily diet of animals and humans. In this study, the dynamics of selenium uptake by the above-ground parts of maize plants were examined under soil fertilization with sodium selenate. The research showed that the application of selenium at low doses of 0.1 and $0.2 \mathrm{mg} \mathrm{kg}^{-1}$ may increase the Se content in maize plants; however, the effect of selenium fertilization on the plants' dry mass yield depended on the varietal property. Maize crops harvested at the beginning of the tassel emergence phase $(\mathrm{BBCH} 51)$ contained an excessive amount of selenium, and maize plants under the Se treatment of $0.1 \mathrm{mg} \mathrm{kg}^{-1}$ were suitable for the production of animal feed after only 81 days of vegetation. Despite this study's valuable contributions, the exact mechanism of selenium detoxification with respect to the plant species and varieties remains unclear. Comparative investigations are needed to establish the threshold levels of selenium toxicity in different maize varieties that 
may result in the activation of a defence mechanism of volatilization. In addition, further research into the effectiveness of other chemical forms of Se in increasing the selenium content to the optimal level in maize and determining the appropriate harvest date for plants intended for animal feeding are necessary.

Author Contributions: Conceptualization, B.P.-P. and A.P.; methodology, B.P.-P. and A.P.; validation and analysis, B.P.-P. and A.P.; draft preparation, A.P., review and editing, A.P. All authors have read and agreed to the published version of the manuscript.

Funding: This research was funded by the Polish Ministry of Science and Higher Education, No. N N310 724440.

Data Availability Statement: The data can be obtained from the corresponding author.

Conflicts of Interest: The author declares no conflict of interest.

\section{References}

1. Ebrahimi, N.; Hartikainen, H.; Simojoki, A.; Hajiboland, R.; Seppanen, M. Dynamics of dry matter and selenium accumulation in oilseed rape (Brassica napus L.) in response to organic and inorganic selenium treatments. Agric. Food Sci. 2015, 24, 104-117. [CrossRef]

2. Wang, J.; Wang, Z.; Mao, H.; Zhao, H.; Huang, D. Increasing Se concentration in maize grain with soil- or foliar-applied selenite on the Loess Plateau in China. Field Crop. Res. 2013, 150, 83-90. [CrossRef]

3. White, J.P. Selenium metabolism in plants. Biochim. Biophys. Acta Gen. Subj. 2018, 1862, 2333-2342. [CrossRef] [PubMed]

4. Wu, Z.; Bañuelos, G.S.; Lin, Z.-Q.; Liu, Y.; Yuan, L.; Yin, X.; Li, M. Biofortification and phytoremediation of selenium in China. Front. Plant Sci. 2015, 6, 136. [CrossRef]

5. Żarczyńska, K.; Żarczyński, P.; Sobiech, P.; Snarska, A.; Stopyra, A.; Wieteska, M.; Płaczek, A. The effect of micronutrient deficiencies on the health status of transition cows. J. Elem. 2017, 22, 1223-1234. [CrossRef]

6. Płaczek, A.; Stępień, P.; Żarczyński, P.; Patorczyk-Pytlik, B. Methods for enrichment of animal diets with selenium. J. Elem. 2019, 24, 1159-1172. [CrossRef]

7. Kruzhel, B.; Bakowska, M.; Vovk, S.; Nowakowska, E.; Sergei, P. Selenium in the diet of ruminants. Acta Sci. Pol. Zootech. 2014, 13, $5-16$.

8. Lyons, M.P.; Papazyan, T.T.; Surai, P.F. Selenium in food chain and animal nutrition: Lessons from nature-review. Asian-Aust. J. Anim. Sci. 2007, 20, 1135-1155. [CrossRef]

9. Suchý, P.; Straková, E.; Herzig, I. Selenium in poultry nutrition: A review. Czech J. Anim. Sci. 2014, 59, 495-503. [CrossRef]

10. Klusonova, I.; Skladanka, J.; Hodulikova, L.; Skarpa, P.; Adam, V. The influence of foliar application of selenium on content of glutathione in the forage of perennial ryegrass (Lolium perenne L.). In Mendel Net, Proceedings of the International Ph.D. Students Conference, Brno, Czech Republic, 11-12 November 2015; Polák, O., Cerkal, R., Březinová Belcredi, N., Eds.; Mendel University: Brno, Czech Republic, 2015; pp. 131-136. Available online: https://mnet.mendelu.cz/mendelnet2015/mnet_2015_full.pdf (accessed on 10 March 2021).

11. Longchamp, M.; Castrec-Rouelle, M.; Biron, P.; Bariac, T. Variations in the accumulation, localization and rate of metabolization of selenium in mature Zea mays plants supplied with selenite or selenate. Food Chem. 2015, 182, 128-135. [CrossRef] [PubMed]

12. Chilimba, A.D.C.; Young, S.D.; Black, C.R.; Meacham, M.C.; Lammel, J.; Broadley, M.R. Agronomic biofortification of maize with selenium (Se) in Malawi. Field Crops Res. 2012, 125, 118-128. [CrossRef]

13. Masanza, B.; Maida, J.H.A.; Chilimba, A.D.C.; Lowole, M.W.; Nalivata, P.C. Liming and selenium application impact on plant available selenium in selected soils of Malawi. J. Soil Sci. Environ. Manage 2016, 7, 115-122. [CrossRef]

14. El-Ramady, H.; Abdalla, N.; Taha, H.S.; Alshaal, T.; El-Henawy, A.; Faizy, S.E.-D.A.; Shams, M.S.; Youssef, S.M.; Shalaby, T.; Bayoumi, Y.; et al. Selenium and nano-selenium in plant nutrition. Environ. Chem. Lett. 2016, 14, 123-147. [CrossRef]

15. Al-Tameemi, H.J.H.; AL-Amiri, N.J.; Hassan, M.J. Effect of Selenium Fertilization on Dry Weight, Concentration, and Sele-nium uptake in Shoot of Maize (Zea mays L.) Growing in Iraqi Calcareous Soils. Merit Res. J. Agric. Sci. Soil Sci. 2018, 6, 001-006. [CrossRef]

16. Płaczek, A.; Patorczyk-Pytlik, B. Changes in the content of selenium in aerial parts of maize varieties, depending on the growing period and soil texture. J. Elem. 2020, 25, 787-800. [CrossRef]

17. Riedell, W.E. Mineral-nutrient synergism and dilution responses to nitrogen fertilizer infield-grown maize. J. Plant Nutr. Soil Sci. 2010, 173, 869-874. [CrossRef]

18. McDowell, L.R.; Valle, G.; Cristaldi, L.; Davis, P.A.; Rosendo, O.; Willinson, N.S. Selenium availability and methods of selenium supplementation for grossing ruminants. In Proceedings of the 13th Annual Florida Ruminant Nutrition Symposium, Gainesville, FL, USA, 11-12 January 2002; pp. 86-102.

19. Xing, K.; Zhou, S.; Wu, X.; Zhu, Y.; Kong, J.; Shao, T.; Tao, X. Concentrations and characteristics of selenium in soil samples from Dashan Region, a selenium-enriched area in China. J. Soil Sci. Plant Nutr. 2015, 61, 889-897. [CrossRef]

20. Meier, U. Growth Stages of Mono- and Dicotyledonous Plants. BBCH. Monograph. Quedlinburg 2018, 28-31. [CrossRef] 
21. Regulation of the Minister of Agriculture and Rural Development of 23 January 2003 “On the Methodology of Analytical Proceedings in the Scope of Determining the Content of Nutrients and Feed Additives in Feed Materials, Prefixes and Compound Feeds" (J. of Laws 66, 614), In Polish. Available online: https:/ /isap.sejm.gov.pl/isap.nsf/DocDetails.xsp?id=WDU20030660614 (accessed on 1 May 2021).

22. Hawrylak-Nowak, B. Changes in Anthocyanin Content as Indicator of Maize Sensitivity to Selenium. J. Plant Nutr. 2008, 31, 1232-1242. [CrossRef]

23. Naseem, M.; Anwar-ul-Haq, M.; Wang, X.; Farooq, N.; Awais, M.; Sattar, H.; Malik, A.H.; Mustafa, A.; Ahmad, J.; El-Esawi, M.A Influence of Selenium on Growth, Physiology, and Antioxidant Responses in Maize Varies in a Dose-Dependent Manner. J. Food Qual. 2021, 9. [CrossRef]

24. Djanaguiraman, M.; Devi, D.D.; Shanker, A.K.; Sheeba, J.A.; Bangarusamy, U. Impact of selenium spray on monocarpic senescence of soybean (Glycine Max L.). J. Food Agric. Environ. 2004, 2, 44-47.

25. Shafiq, S.; Adeel, M.; Raza, H.; Iqbal, R.; Ahmad, Z.; Naeem, M.; Sheraz, M.; Ahmed, U.; Azmi, U.R. Effects of Foliar Application of Selenium in Maize (Zea Mays L.) under Cadmium Toxicity. Biol. Forum 2019, 11, 61-71.

26. Ashraf, M.A.; Akbar, A.; Parveen, A.; Rasheed, R.; Hussain, I.; Iqbal, M. Phenological application of selenium differentially improves growth, oxidative defense and ion homeostasis in maize under salinity stress. Plant Physiol. Biochem. 2018, 123, 268-280. [CrossRef] [PubMed]

27. Kaur, S.; Singh, D.; Singh, K. Effect of selenium application on arsenic uptake in rice (Oryza sativa L.). Environ. Monit. Assess 2017, 189, 430. [CrossRef]

28. Kaur, M.; Sharma, S. Influence of selenite and selenate on growth, leaf physiology and antioxidant defense system in wheat (Triticum aestivum L.). J. Sci. Food Agric. 2018, 98, 5700-5710. [CrossRef]

29. Liu, X.; Zhao, Z.; Hu, C.; Zhao, X.; Guo, Z. Effect of sulphate on selenium uptake and translocation in rape (Brassica napus L.) supplied with selenate or selenite. Plant Soil 2016, 399, 295-304. [CrossRef]

30. Cartes, P.; Gianfreda, L.; Mora, M. Uptake of Selenium and its Antioxidant Activity in Ryegrass When Applied as Selenate and Selenite Forms. Plant Soil 2005, 276, 359-367. [CrossRef]

31. Thavarajah, D.; Thavarajah, P.; Vial, E.; Gebhardt, M.; Lacher, C.; Kumar, S.; Combs, G.F. Will selenium increase lentil (Lens culinaris Medik) yield and seed quality? Front. Plant Sci. 2015, 6. [CrossRef]

32. Boldrin, P.F.; Faquin, V.; Ramos, S.J.; Boldrin, K.V.F.; Ávila, F.W.; Guimarães Guilherme, L.R. Soil and foliar application of selenium in rice biofortification. J. Food Compos. Anal. 2013, 31, 238-244. [CrossRef]

33. Sharma, S.; Bansal, A.; Dhillon, S.K.; Dhillon, K.S. Comparative effects of selenate and selenite on growth and biochemical composition of rapeseed (Brassica napus L.). Plant Soil 2010, 329, 339-348. [CrossRef]

34. Sarwar, N.; Akhtar, M.; Kamran, M.A.; Imran, M.; Riaz, M.A.; Kamran, K.; Hussain, S. Selenium biofortification in food crops: Key mechanisms and future perspectives. J. Food Compos. Anal. 2020, 93, 103615. [CrossRef]

35. Mombo, S.; Schreck, E.; Dumat, C.; Laplanche, C.; Pierart, A.; Longchamp, M.; Besson, P.; Castrec-Rouelle, M. Bioaccessibility of selenium after human ingestion in relation to its chemical species and compartmentalization in maize. Environ. Geochem. Health 2016, 38, 869-883. [CrossRef]

36. Song, T.; Su, X.; He, J.; Liang, Y.; Zhou, T.; Liu, C. Selenium (Se) uptake and dynamic changes of Se content in soil-plant systems. Environ Sci. Pollut. Res. 2018, 25, 34343-34350. [CrossRef] [PubMed]

37. Hefnawy, A.E.G.; Tórtora-Pérez, J.L. The importance of selenium and the effects of its deficiency in animal health. Small Rumin. Res. 2010, 89, 185-192. [CrossRef]

38. Zhang, M.; Tang, S.; Huang, X.; Zhang, F.; Pang, Y.; Huang, Q.; Yi, Q. Selenium uptake, dynamic changes in selenium content and its influence on photosynthesis and chlorophyll fluorescence in rice (Oryza sativa L.). Environ. Exp. Bot. 2014, 107, 39-45. [CrossRef]

39. Yang, F.; Chen, L.; Hu, Q.; Pan, G. Effect of the application of selenium on selenium content of soybean and its products. Biol Trace Elem Res. 2003, 93, 249-256. [CrossRef]

40. Seppänen, M.M.; Ebrahimi, N.; Kontturi, J.; Hartikainen, H.; Lopez Heras, I.; Cámara, C.; Madrid, Y. Dynamics of selenium uptake and metabolism of organic selenium species in the leaves and seeds of Brassica napus L. Agric. Food Sci. 2018, 27, 38-49. [CrossRef]

41. Jiang, Y.; Zeng, Z.H.; Bu, Y.; Ren, C.Z.; Li, J.Z.; Han, J.J.; Tao, C.; Zhang, K.; Wang, X.X.; Lu, G.X.; et al. Effects of selenium fertilizer on grain yield, Se uptake and distribution in common buckwheat (Fagopyrum esculentum Moench). Plant Soil Environ. 2015, 61, 371-377. [CrossRef]

42. White, P.J. Selenium accumulation by plants. Ann. Bot. 2016, 117, 217-235. [CrossRef]

43. Gupta, M.; Gupta, S. An Overview of Selenium Uptake, Metabolism, and Toxicity in Plants. Front. Plant Sci. 2017, 7, 2074. [CrossRef]

44. Terry, N.; Zayed, A.M.; de Souza, M.P.; Tarun, A.S. Selenium in higher plants. Ann. Rev. Plant Physiol. 2000, 51, 401-432. [CrossRef]

45. Pilon-Smits, E.A.H.; Quinn, C.F. Selenium metabolism in plants. In Cell Biology of Metals and Nutrients; Hell, R., Mendel, R.-R., Eds.; Springer: Berlin/Heidelberg, Germany, 2010; Volume 17, pp. 225-241. [CrossRef]

46. Winkel, L.H.; Vriens, B.; Jones, G.D.; Schneider, L.S.; Pilon-Smits, E.; Bañuelos, G.S. Selenium cycling across soil-plant-atmosphere interfaces: A critical review. Nutrients 2015, 7, 4199-4239. [CrossRef] 